\title{
GEOLOGICAL BACKGROUND OF THE PRESENT REGIONAL UPLIFT ANOMALY IN ESTONIA
}

\author{
Avo MIIDEL
}

Eesti Teaduste Akadeemia Geoloogia Instituut (Institute of Geology, Estonian Academy of Sciences), Estonia pst. 7, EE-0100 Tallinn, Eesti (Estonia)

Presented by A. Raukas

Received November 24, 1993; accepted December 8, 1993

\begin{abstract}
It has been ascertained that the regional uplift anomaly which was established by Svensson $(1989,1991)$ and the central part of which is largely situated in Estonia, is not reflected at the Moho depth, in the anomalies of temperature (measured at a depth of $200 \mathrm{~m}$ ) and heat flow. The uplift anomaly is related neither to helium anomalies nor the surface of the crystalline basement. However, it is connected with some tectonic fracture zones and recent crustal movements. Thus, it is rather obvious that the NW and SE boundaries of the anomaly are of tectonic origin. They are situated in tectonically active fracture zones. The well-known and best-studied Pärnu-Tapa-Kunda zone is located at the SE boundary of the uplift anomaly. This fracture zone is of Proterozoic age, but in the Phanerozoic it has repeatedly revived, last in the Pleistocene and Holocene.
\end{abstract}

Key words: present uplift anomaly, basement, Moho depth, heat flow, helium anomalies, fracture zones, recent crustal movements.

\section{INTRODUCTION}

Lately Svensson $(1989,1991)$ pointed out that at the present time NW Estonia was rising faster than expected. The regional anomaly, spreading over NW Estonia and SE Finland, was established by Svensson as a deviation in the present uplift from the mean value of the ratio between the Baltic Ice Lake shoreline and the present uplift rate.

Since a substantial part of the regional anomaly lies within Estonia, its relations to some features of the Estonian geology are of interest. To study the problem, we made use of the data available on the Moho depth (Fig. 1), topography of the crystalline basement (Fig. 2), distribution of temperature at a depth of $200 \mathrm{~m}$ (Fig. 3) and heat flow (Fig. 4), helium anomalies (Fig. 5), fracture tectonics (Fig. 6), and recent crustal movements (Fig. 7). 


\section{MOHO DEPTH}

The only data on crust and lithosphere structures in Estonia have been presented by Bulin (Булин, 1978). Having studied the Osmussaar earthquake area (NW Estonia), he established that there the Moho depth ranged from $47 \mathrm{~km}$ in the north to $42 \mathrm{~km}$ in the south. Of course, there are small-scaled maps, showing the Moho depth, crustal thickness, etc. mainly in Fennoscandia (Babuška et al., 1988; Marquart, 1989; Luosto, 1991; a.o.). However, on the basis of these maps it is very difficult to find out direct connections between the material presented on these maps and the geology of small, though in many aspects intensively studied areas, like Estonia.

The latest data (Korja et al., 1993) suggest that the thickness of the crust ranges from 46 to $56 \mathrm{~km}$. According to a map compiled on their basis (Fig. 1), Estonia is located on the northern slope of the Moho depression, oriented in the east-west direction. The regional anomaly intersects the Moho depression independently (Fig. 1). Only its maximum runs parallel to the northwestern slope of the Moho depression. Nevertheless, it is difficult to believe that this coincidence is indicative of a direct connection between the regional uplift anomaly and the Moho depression. Neither the data on the depth nor the thickness of the lowermost high-velocity crustal layer support this connection (cf. Figs. 4 and 4 b in Korja et al., 1993).

In 1970-72 magnetotelluric measurements were made at 19 sites (Андра et al., 1974). Interpretation of the results yielded $75 \mathrm{~km}$ for the mean depth of the layer of high conductivity. Since the number of measurement sites was small it is impossible to map regional differences in the depth of the layer of high conductivity. The standard deviation of the mean is $2.3 \mathrm{~km}$. Thus, these data are of little consequence for regional land uplift anomaly studies.

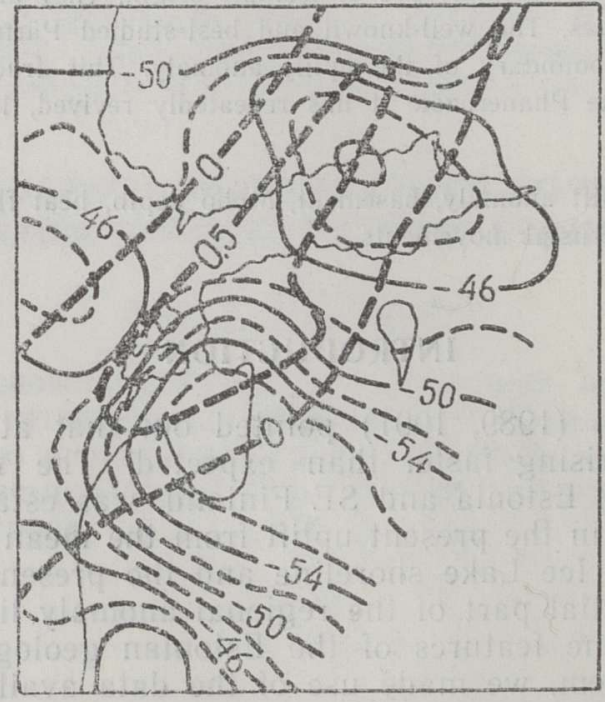

Fig. 1. Crustal depth (Moho) in km after Luosto (Korja et al., 1993). Uplift anomaly shown in thick in Figs. 1-7. 


\section{TOPOGRAPHY OF THE CRYSTALLINE BASEMENT}

Fig. 2 shows that the basement lowers rather evenly toward the south and southeast. There is no connection between the NE-SW oriented regional uplift anomaly and the basement topography. The location of zero isoline on the NW slope of the Valmiera-Lokno basement uplift is evidently occasional. So, the SW-NE orientation of the uplift anomaly is not determined by the basement topography.

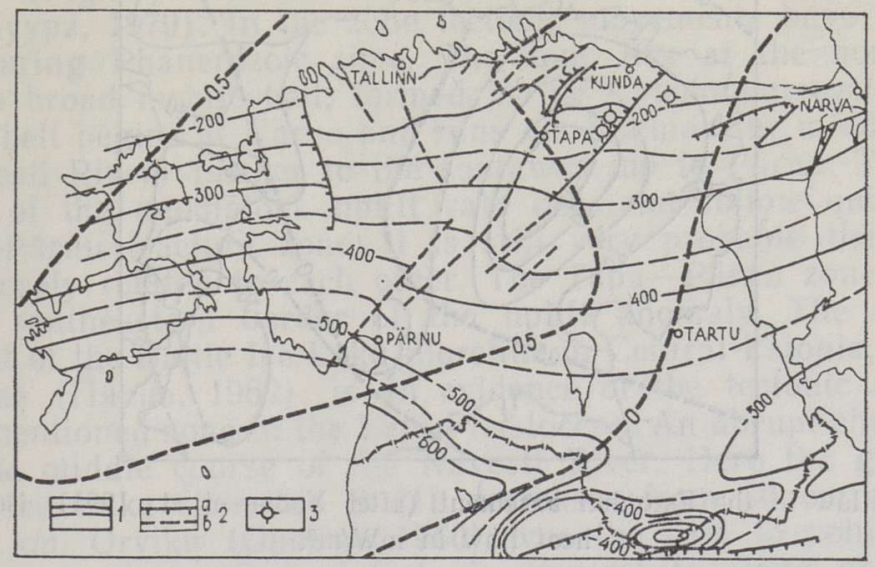

Fig. 2. Surface of the Estonian basement after Puura (Пуyра, 1983).

1 isohypses of the basement; 2 fracture zones, (a) with a scarp, (b) scarp not established; 3 local elevations of the basement.

\section{TEMPERATURES AND HEAT FLOW}

Some years ago maps of the temperatures at a depth of $200 \mathrm{~m}$ and heat flow in the northern part of the Baltic syneclise were compiled (Урбан et al., 1991; Figs. 3 and 4). In both maps two anomalies can be distinguished. Their shape is partly determined by deep-seated and other kinds of fracture zones. It is supposed that the anomaly located in NE Estonia belongs to a zone of the higher heat flow extending all over the Baltic syneclise. As pointed out by Urban (Урбан, 1991; Урбан et al., 1991), an anomalous heat flow is caused by the neotectonic activity of fracture zones.

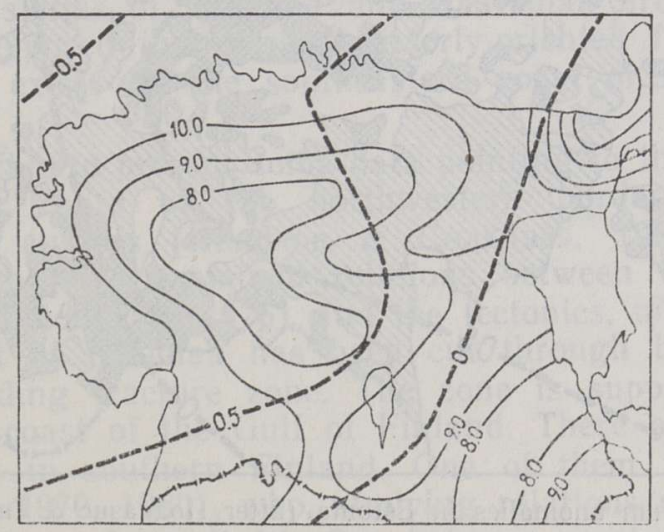

Fig. 3. Distribution of temperatures at a depth of $200 \mathrm{~m}$ (after Урбан et al., 1991). 
A comparison of geothermal maps with the land uplift anomaly (Figs. 3 and 4 ) did not reveal any distinct connection between them. Though the southeastern border of the anomaly (zero isoline) follows the highest values of temperature and heat flow (Fig. 4), this cannot be considered as a firm evidence of causality between land uplift and geothermal anomalies. This connection would be geologically difficult to explain.

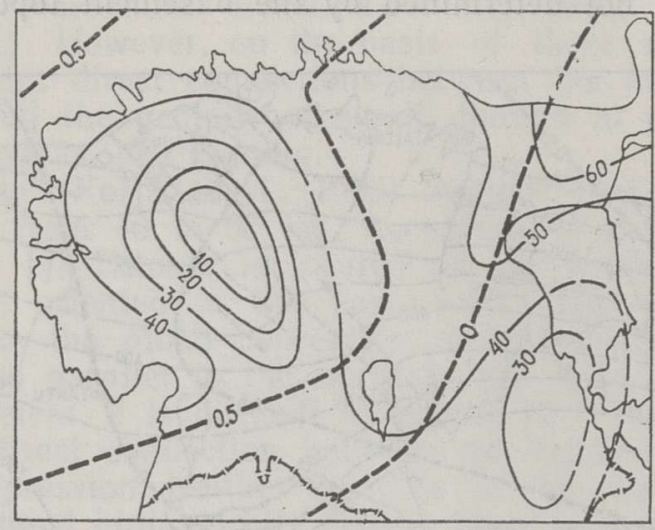

Fig. 4. Heat flow in the Estonian basement (after Урбан et al., 1991); isolines of the heat flow in $\mathrm{mW} / \mathrm{m}^{2}$.

\section{HELIUM ANOMALIES}

The results of helium mapping (Иодказис \& Тибар, 1989; Fig. 5) do not reveal any features which would reflect the land uplift anomaly either. The northwestern course of the 0.5 isoline along the border of a negative helium anomaly seems to be the only common feature. It is known that the same 0.5 isoline between Pärnu Bay and Lake Võrtsjärv coincides with a fracture distinguished on the basis of helium content.

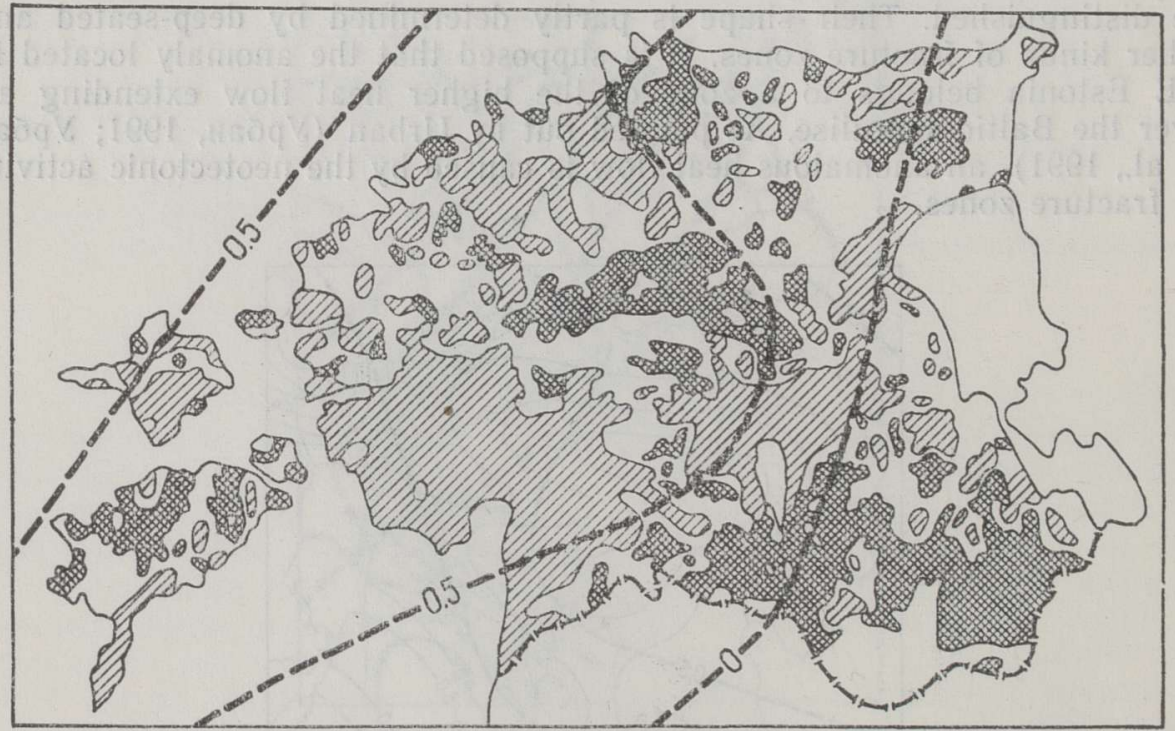

Fig. 5. Helium anomalies in Estonia (after Иодказис \& Тибар, 1989).

Cross-lined areas-negative anomalies, white areas-helium content normal, striped areas-positive anomalies. 


\section{FRACTURE ZONES}

Geophysical data indicate that there are several large deep-seated fault zones in the basement among which the most prominent are the northwesterly-oriented Paldiski-Pskov and west-east-oriented CentralEstonian zones of Early and Late Proterozoic age (Пуура, 1979). In the regional uplift anomaly neither of them is traceable.

Of great interest is a large tectonic zone along the Kunda-TapaPärnu line (Fig. 6). The zone is also inherited from the Early Proterozoic (Пуypa, 1979). In the zone tectonic movements have repeatedly occurred during Phanerozoic time. The zone lies at the northwestern border of a broad mobile belt, formed in the Caledonian cycle (Пууypa, 1979). The belt begins at Narva and runs via Võhma (the middle reaches of the Navesti River) further to the southwest up to Pärnu. Though the 0.5 isoline of the anomalous uplift rate does not follow quite exactly the Tapa-Pärnu fracture zone, it is still very probable that actually they are closely related to each other. The Tapa-Pärnu zone evidently marks the southeastern border of the uplift anomaly. The change in the gradient of the Baltic Ice Lake shoreline in Central Estonia, determined by Pärna (Пярна, 1962), is an evidence of the tectonic activity of the above-mentioned zone in the Late Pleistocene. An abrupt change takes place in the middle course of the Navesti River. Here the gradient of the Baltic Ice Lake shoreline B III decreases from $30 \mathrm{~cm}$ per $\mathrm{km}$ to $18 \mathrm{~cm}$ per $\mathrm{km}$. Orviku (Орвику, 1960) was the first to point out that this was due to the revival of tectonic movements along an old zone of weakness. Later the conclusion was confirmed by geodetic and geomorphological data (Уттер, 1964; Zhelnin, 1966; Мийдел, 1966; Орвику, 1969). Thus, all available geological data indicate that the southeastern border of the land uplift anomaly is situated namely in the KundaTapa-Pärnu fracture zone. At last, it ought to be mentioned that there is no acceptable geological explanation for the strange curvature in the 0.5 isoline of the uplift rate in Central Estonia. According to Pärna (Пярна, 1962) there are serious errors in the heights of the Baltic Ice Lake shoreline presented by Ramsay (1929). If Pärna's doubts are grounded, then the course of the 0.5 isoline in Central Estonia could be explained by inaccuracies in the data used.

It is much more complicated to find geological evidence for outlining the northwestern border of the uplift anomaly. Above all, this border should be reflected in the geological structure of the sea bottom, but the latter has been insufficiently studied so far. Moreover, data on the tectonics of the islands of Hiiumaa and Saaremaa are inadequate. It has been only supposed that a northeasterly-oriented fracture zone in Palaeozoic rocks exists on the southeastern coast of Hiiumaa Island (Fig. 6).

Still it is possible to present some data pointing to the northeasterlytrending fracture zones at the northwestern border of the uplift anomaly. Several authors (Никонов \& Сильдвээ, 1988; Кондорская et al., 1988), who have examined relations between the Osmussaare earthquake (NW Estonia, in 1976) and the tectonics, maintain that the northwestern part of Hiiumaa has been cut through by an extensive northeasterly-trending fracture zone. The zone is supposed to run as far as the north coast of the Gulf of Finland. There are data on two active hinge-lines in southern Finland. One of them was established by Donner $(1966,1970,1980)$, who, studying relations of the late- and postglacial shorelines of the Baltic Sea between southern Finland and Estonia, found that they could not be connected with straight lines. 


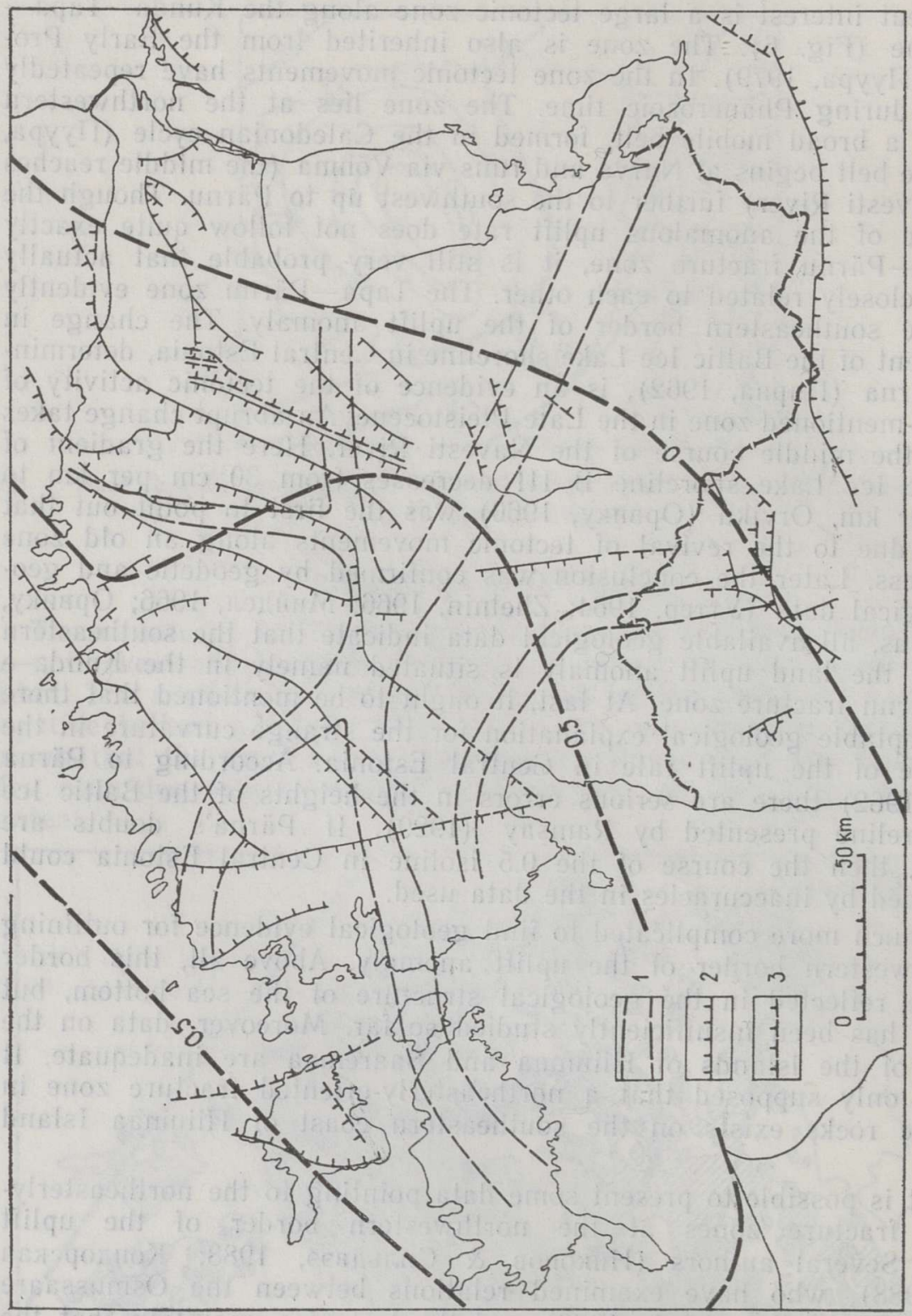

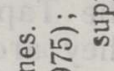

동

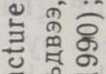

ह5

ธै

홀

.

음

吨

园

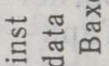

品

츨 츨

응 중

등뭉

亏 छ

0 羟

过蒙

ह

路

ङ

E

อ

올

는

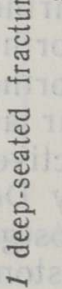


The shoreline gradients decrease considerably in the area of the Gulf of Finland. This hinge-line, which is expressed as a bend and is according to Donner evidently tectonically controlled, proceeds further in the northeastern direction as far as the north coast of Lake Ladoga. Kondorskaya et al. (Кондорская et al., 1988) maintain that this hingeline is connected with the above-mentioned fracture zone on Hiiumaa Island. After Jantunen (1990), another hinge-line is located in the Lahti-Pikkala fault zone, which is one of the longest and best observable fault lines in the topography of southern Finland. Precise repeated levelling data show that this fault line is active at present as well. Kääriäinen's uplift map (Kääriäinen, 1963) suggests the same: the gradient of land uplift changes considerably between Helsinki and Hanko. Some NE-SW-oriented active seismotectonic fracture zones of the Loviisa area (Saari, 1992) are probably connected with the first hinge-line. Therefore, it is likely that at least one of these hinge-lines marks the northwestern boundary of the land uplift anomaly.

\section{RECENT CRUSTAL MOVEMENTS}

Among numerous maps showing recent crustal movements the map compiled by Vallner et al. (1988) is of particular interest (Fig. 7). Compared to earlier maps its peculiarity consists in depicting an area located in West Estonia and bordered from the northwest and southeast by an uplift isobase of $2 \mathrm{~mm}$. In this area the land uplift is nearly uniform. Isobases are not distributed evenly over Estonia's territory, but converge into groups. This is, in all likelihood, the result of the land uplift taking place at different rates and step by step. Therefore, land uplift can be assumed to occur along the NE-SW-oriented fracture zones. So far this assumption has found confirmation only in case of the above-mentioned Kunda-Tapa-Pärnu fracture zone. To state the same about the dislocation in NW Estonia would be too hasty though there is a fracture zone running in the same direction (Fig. 7).

Serious attention should be paid to the location of the two belts of recent crustal movements which occur in the immediate vicinity of the land uplift anomaly and run parallel to its isobases. Consequently, the character of recent crustal movements seems to confirm the land uplift anomaly in Estonia. At the same time it might explain the peculiar distribution of the isobases of present-day movements in the western part of Estonia. There are a number of earthquake epicentres on the northwestern boundary of the uplift anomaly, in the gradient zone of recent crustal movements or in its neighbourhood. This might be an additional evidence of an approximately NE-SW-oriented fracture zone in NW Estonia. However, it must be admitted that this supposition is not in good accordance with the hitherto existing data on the distribution of fracture zones in West Estonia (Fig. 6).

It is not yet clear either how the gradient zone of recent crustal movements in the northern part of Lake Vorrtsjärv is related to the land uplift anomaly. In the same region several earthquakes have been registered, too. Nevertheless, it seems more realistic that this gradient zone is connected with the central area of uplift anomaly rather than its zero isoline. Yet it is supposed that the above-mentioned earthquake epicentres lie within the Paldiski-Pskov deep-seated fault zone (Sildvee, 1991). 


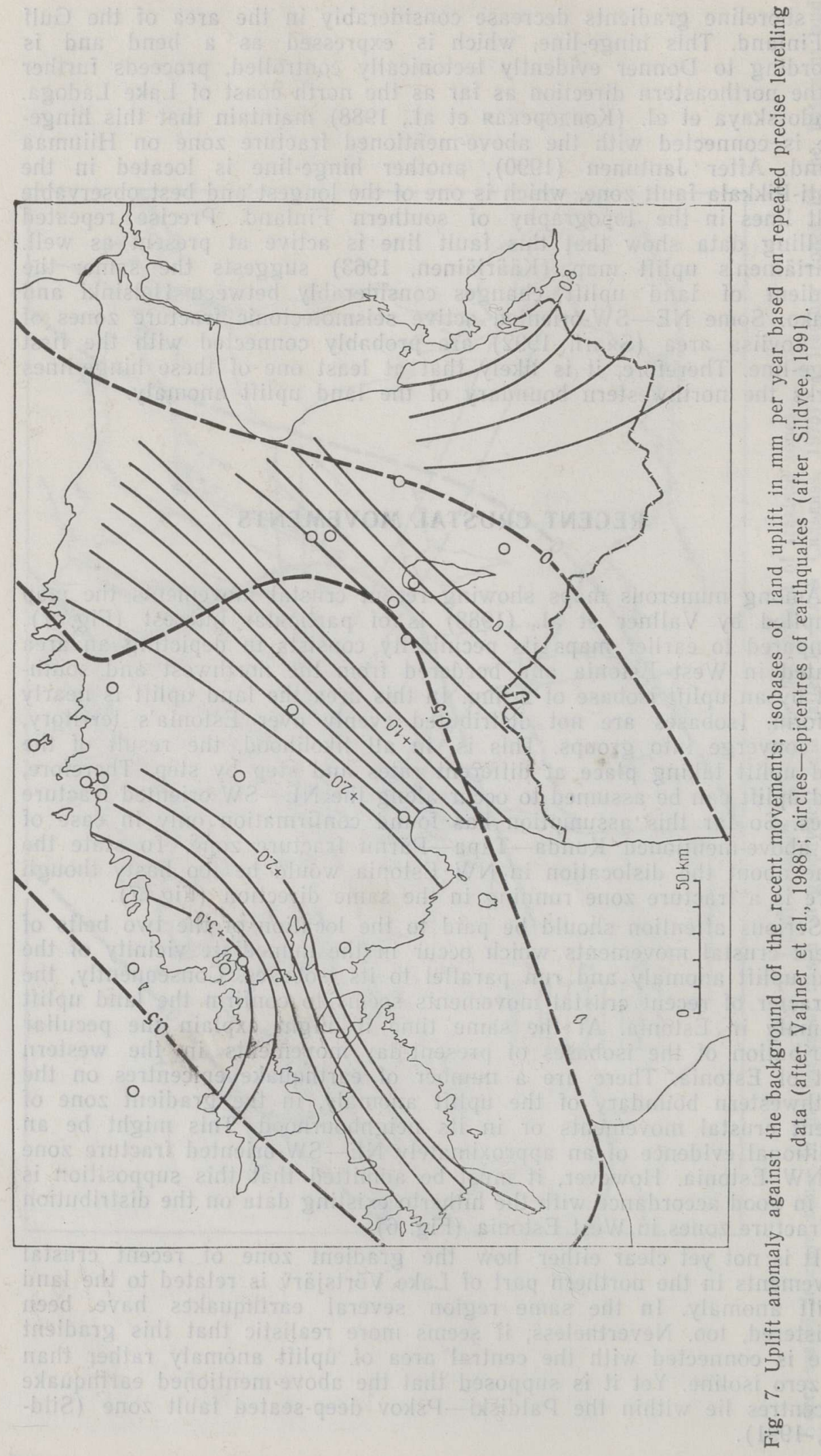


There is a surprisingly good coincidence between the land uplift anomaly and the area in North Estonia established on the basis of tide-gauge records by Emery \& Aubrey (1985). This area is rising at a very high rate. Its central part rises annually at least $8 \mathrm{~mm}$ (Fig. 8). Regardless of certain geological preconditions the existence of this structure is disputable to a high degree, maybe even unlikely (Miidel, 1992). The more so since its separation is based only on the studies conducted at two pre-war stations by 11 -year spans. However, the fact itself is worth mentioning.

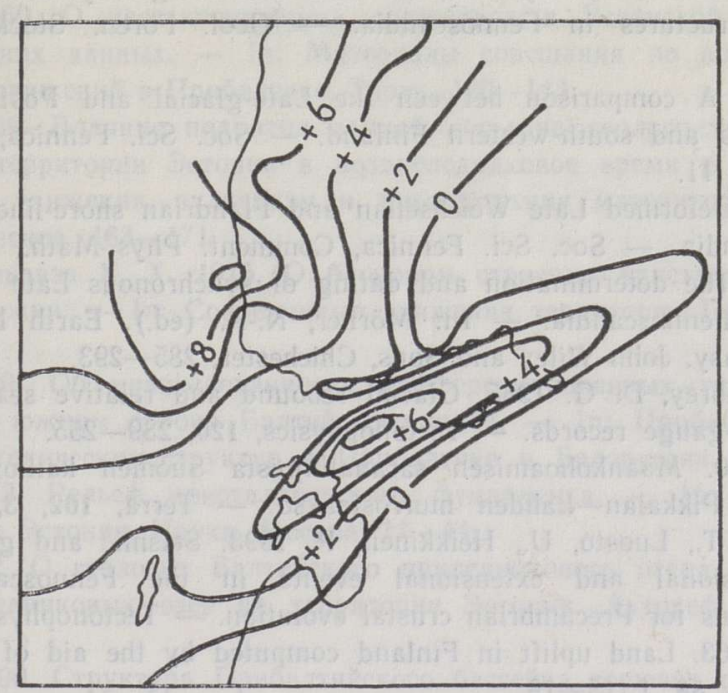

Fig. 8. Land uplift anomaly in Estonia based on tide-gauge records (after Emery \& Aubrey, 1985).

\section{CONCLUSIONS}

It follows from the above-said that, probably, not all features of the geological structure were related to the land uplift anomaly. First of all this applies to the data concerning some features of the deep crust structure (Moho depth, temperature and heat flow, helium anomalies). Connections with fracture zones seem to be better. Some fracture zones follow the NW and SE boundaries of the central part of the anomaly. The SE boundary lies in the Tapa-Pärnu fracture zone, which formed in the Proterozoic. As to the tectonic dislocations marking the NW boundary one can find reliable data mainly from southern Finland from where fracture zones continue as far as the NW coast of Hiiumaa Island, Estonia. It is supposed that the Osmussaare earthquake took place namely in one of such $\mathrm{NE}$ - SW-oriented fracture zones. These conclusions are supported by data on recent crustal movements from West and Central Estonia.

Summing up, it may be stated that there are certain geological evidences in Estonia of the land uplift anomaly established by Svensson (1989, 1991). 


\section{ACKNOWLEDGEMENTS}

The author thanks his colleagues Anto Raukas for valuable critical remarks, Helle Kukk for linguistic improvements, Urve Pohl for typing the manuscript, and Paul Pärkma for the drawings.

\section{REFERENCES}

Babuška, V., Plomerová, J., Pajdušák, P. 1988. Seismologically determined deep lithosphere structures in Fennoscandia. - Geol. Fören. Stockholm Förh., 110, $380-382$.

Donner, J. 1966. A comparison between the Late-glacial and Post-glacial shorelines in Estonia and south-western Finland. - Soc. Sci. Fennica, Comment. Phys.Math., 31, 11.

Donner, J. 1970. Deformed Late Weichselian and Flandrian shore-lines in south-eastern Fennoscandia. - Soc. Sci. Fennica, Comment. Phys.-Math., 40, 191-198.

Donner, J. 1980. The determination and dating of synchronous Late Quaternary shorelines in Fennoscandia. - In: Mörner, N.-A. (ed.). Earth Rheology, Isostasy and Eustasy. John Wiley and Sons, Chichester, 285-293.

Emery, K. O., Aubrey, D. G. 1985. Glacial rebound and relative sea levels in Europe from tide-gauge records. - Tectonophysics, 120, 239-255.

Jantunen, T. 1990. Maankohoamisen saranalinjoista Suomen kallioperässa: tutkimuskohteena Pikkalan-Lahden murroslaakso. - Terra, 102, 3, 158-163.

Korja, A., Korja, T., Luosto, U., Heikkinen, P. 1993. Seismic and geoelectric evidence for collisional and extensional events in the Fennoscandian Shield implications for Precambrian crustal evolution. - Tectonophysics, 219, 129-152.

Kääriäinen, E. 1963. Land uplift in Finland computed by the aid of precise levellings. - Fennia, 89, 1, 15-19.

Luosto, U. 1991. Moho Depth Map of the Fennoscandian Shield Based on Seismic Refraction Data. Inst. of Seismology, University of Helsinki. Report S-25, $43-50$

Marquart, G. 1989. Isostatic topography and crustal depth corrections for the Fennoscandian geoid. - Tectonophysics, 169, 67-77.

Miidel, A. 1992. Vaateid maakoore nüüdisliikumistest Eestis. - In: Eesti Geograafia Seltsi Aastaraamat, 27. köide. Valgus, Tallinn, 5-17.

Ramsay, W. 1929. Niveauverschiebungen, eisgestaute Seen und Recession des Inlandeises in Estland. - Fennia, 52, 2.

Saari, J. 1992. A Review of the Seismotectonics of Finland. Report YJT-92-29.

Sildvee, H. 1991. Eesti maavärinad ei jää kahe silma vahele. - Eesti Loodus, 12, 699-701.

Svensson, N.-O. 1989, Late Weichselian and Early Holocene shore displacement in the Central Baltic, based on stratigraphic and morphological records from eastern Smäland and Gotland, Sweden. - Lundqua Thesis, 25.

Svensson, N.-O. 1991. Postglacial land uplift patterns of south Sweden and the Baltic Sea region. - Terra Nova, 369-378.

Zhelnin, G. 1966. On the recent movements of the Earth's surface in the Estonian S.S.R. - Ann. Acad. Sci. Fennicae. Ser. A III. Geol.-Geogr., 90, 489-493.

Vallner, L., Sildvee, H., Torim, A. 1988. Recent crustal movements in Estonia. J. Geodynamics, 9, 215-233.

Андра Х., Вахер Р., Побул Э., Юрине И. 1974. Результаты магнитотеллурических исследований в Эстонии. - Изв. АН ЭССР. Хим. Геол., 23, 1, 50-53.

Булин Н. К. 1978. Глубинное строение Северо-Западной Эстонии по данным МОВЗ. - Советская геология, 5, 123-129.

Вахер Р. М. 1983. Тектоника фосфоритно-сланцевого бассейна Северо-Восточной Эстонии. Автореф. канд. дис. Минск. 
Иодказис В. И., Тибар К. О. 1989. Распределение гелия в подземных водах северного склона Прибалтийского артезианского бассейна. - Советская геология, $5,106-115$.

Кондорская Н. В., Никонов А. А., Ананьин И. В., Корхонен Х., Архе К., Долгополов Д. В., Сильдвээ Х. Х. 1988. Осмуссаареское землетрясение в Восточной Балтике. - Изв. АН СССР. Физика Земли, 5, 5-11.

Мийдел А. 1966. О связи между современными движениями земной коры и эрозионно-аккумулятивной деятельностью рек Эстонии. - Изв. АН ЭССР. Сер. физ.-матем. и техн. н., XV, 1, 121-133.

Никонов А., Сильдвээ Х. 1988. Землетрясения в Эстонии и их сейсмотектоническая позиция. - Изв. АН ЭССР. Геол., 37, 3, 127-142.

Орвику К. К. 1960. О неотектонических движениях в Әстонской ССР на основе геологических данных. - In: Материалы совещания по вопросам неотектонических движений в Прибалтике. Тарту, 120-143.

Орвику К. К. 1969. Влияние поднятия земной коры на геолого-геоморфологическое развитие территории Эстонии в позднеледниковое время и голоцене. - In: Новейшие движения, вулканизм и землетрясения материков и дна океанов. Наука, Москва, 163-171.

Побул Э. А., Сильдвээ Х. Х. 1975. О блоковом строении кристаллического фундамента Эстонии. - In: Современные движения территории Прибалтики. Тарту, $64-73$.

Пуура В. А. 1979. Об унаследованности дифференцированных тектонических движений на южном склоне Балтийского щита. - In: Проблемы унаследованности тектонических структур в Прибалтике и Белоруссии. Таллинн, 13-19.

Пуура В. А. 1983. Рельеф кристаллического фундамента. - In: Кристаллический фундамент Эстонии. Наука, Москва, 11-14.

Пярна К. Т. 1962. О геологии Балтийского приледникового озера и крупных местных приледниковых озер на территории Эстонии. Автореф. канд. дис. Таллинн.

Туулинг И. И. 1990. Структура Прибалтийского бассейна горючих сланцев и фосфоритов. Автореф. канд, дис. Минск.

Урбан Г. 1991. Новые определения теплового потока в пределах тепловой аномалии Балтийской синеклизы. - Изв. АН Эстонии. Геол., 40, 1, 24-32.

Урбан Г., Цыбуля Л., Козел В., Шмидт А. 1991. Геотермическая характеристика северной части Балтийской синеклизы. - Изв. АН Эстонии. Геол., 40, 3, $112-121$.

Уттер Л. Р. 1964. Попытка геологической интерпретации схемы изобаз территории Эстонской CCP. - In: Современные и новейшие движения земной коры в Прибалтике. Минтис, Вильнюс, 94-100.

\section{REGIONAALSE MAATÕUSU KERKEANOMAALIA GEOLOOGILINE TAUST EESTIS}

\section{Avo MIIDEL}

N.-O. Svenssoni $(1989,1991)$ poolt Balti jääjärve rannajoone kõrguse ja nüüdismaatõusu kiiruse seose abil kindlaks tehtud regionaalse maatõusu kerkeanomaalia on jälgitav ka Eestis. Maatõusu kerkeanomaalia ei ilmne Moho pinna sügavuses, geotermikas ja heeliumi anomaaliates. Tal puudub side aluskorra reljeefiga ja osalt ka süvariketega. Maatõusu kerkeanomaalia kagu- ja loodepiir on määratud tektooniliste rikketsoonidega. Kagupiir kulgeb tektooniliselt aktiivsel Pärnu-Tapa-Kunda joonel. Loodepiir on seotud tõenäoliselt kirde-edela-suunaliste rikketsoonidega, mis algavad Lõuna-Soomest ja jätkuvad Soome lahe põhjas Hiiumaale. Neid tsoone iseloomustab seismiline aktiivsus ja ühes neist toimus 1976. aastal Osmussaare maavärin. Maatõusu kerkeanomaalia mõlemad piirid on selgelt jälgitavad maakoore nüüdisliikumiste skeemil. See kinnitab nende tektoonilist olemust. 


\title{
ГЕОЛОГИЧЕСКИИ ФОН РЕГИОНАЛЬНОЙ АНОМАЛИИ СОВРЕМЕННОГО ПОДНЯТИЯ В ЭСТОНИИ
}

\author{
Аво МИИДЕЛ
}

На основе корреляционной связи между высотой последней береговой линии Балтийского ледникового озера и скоростью современных движений земной коры Н.-О. Свенссоном (Svensson, 1989, 1991) установлена региональная аномалия поднятия. Ее центральная часть захватила и Әстонию. В статье рассмотрена связь аномалии с геологическим строением Эстонии. Установлено, что аномалия поднятия не проявляется в глубине Мохо, геотермике и аномальной гелиеносности. Связь отсутствует также с рельефом фундамента и, частично, с глубинными нарушениями. Выяснено, что северо-западная и юго-восточная границы аномалии предопределены зонами тектонических нарушений, в частности последняя, простирающаяся вдоль тектонически мобильной зоны Пярну-Тапа-Кунда. Северо-западная граница связана, вероятно, с зонами нарушений северо-восточного простирания, начинающимися в Южной Финляндии и достигающими по дну Финского залива о-ва Хийумаа. Эти зоны сейсмически активные. В 1976 г. в одной из них произошло Осмуссаареское землетрясение. Обе границы аномального поднятия ясно прослеживаются в современных движениях земной коры, что еще раз подтверждает тектоническую природу границ аномалий. 